\title{
Volatility Risk and January Effect: Evidence from Japan
}

\author{
Jingya $\mathrm{Li}^{1} \&$ Jian Gong ${ }^{1}$ \\ ${ }^{1}$ Faculty of Business Administration, University of Macau, Macau, China \\ Correspondence: Jian Gong, Faculty of Business Administration, University of Macau, E22, Avenida da \\ Universidade, Taipa, Macau, China. E-mail: yb17003@umac.mo
}

Received: March 23, 2015

Accepted: April 2, 2015

Online Published: May 25, 2015

doi:10.5539/ijef.v7n6p25

URL: http://dx.doi.org/10.5539/ijef.v7n6p25

\begin{abstract}
We use a time-series GARCH approach to investigate the January effect in the Japanese stock market. We find that the January effect is more pronounced before the anomaly is released to the public. We provide some evidence that the decline in the degree of January effect can be partially attributed to the long-term Japanese economic recession during the entire 1990s. We find that volatility risk is higher in January. But the higher volatility risk is not the primary cause for January effect. We find some evidence that risk compensation can explain the average market returns in January.
\end{abstract}

Keywords: seasonality, January effect, Japanese stock market, volatility risk, GARCH model

\section{Introduction}

In a recent study, Sun and Tong (2010) use the U.S. stock market index to reexamine whether January effect is caused by market volatility risk and find that market volatility is not significantly higher in January. Rather, they provide evidence that January effect is caused by the higher risk compensation in January. This study applies Sun and Tong (2010)'s methodology to Japanese market and tests whether their findings are applicable to the stock market outside the U.S. The reason to choose Japanese market is that prior literature provides evidence about the capital market integration between the two countries (Campbell \& Hamao, 1992).

Following Sun and Tong (2010), we use GARCH models to investigate the relation between volatility risk and January effect for the Japanese stock market. Our findings are as follows. Consistent with Kato and Schallheim (1985), we show that the January effect is pronounced for the Japanese stock market over the period from 1975 to 2008 (Note 1). The January effect is greater over the sub-period from 1975 to 1984, the time before the market anomaly is released to the public. Additional evidence indicates that the January effect is more pronounced for the stock portfolios consisting of large firms in the sub-period 1985-2008. Consistent with Rogalski and Tinic (1986), we find that volatility risk is priced in January. But the volatility risk is not the cause for January effect. We also find some evidence that risk compensation can explain the market returns in January over the sub-period 1985-2008.

This research adds to the literature on seasonal anomalies. We provide evidence that the degree of January effect declines after the release of the market anomaly. We argue that the long-term Japanese economic recession may also contribute to the lower degree of January effect from 1985 to 2008 . We show that the market turnover declines sharply in the early 1990s and stays at a low level during the entire 1990s. Second, this research adds to literature by revealing that in the sub-period 1975-1984 volatility risk is lower but it is higher priced for large firms. It implies that investors can make more profits by bearing less risk if they take use of the anomaly. We provide evidence that the profit-making opportunity disappears in the following years. The result implies that market dysfunction does not persist in the long run. Third, this research adds to literature by providing evidence that although risk compensation cannot explain January effect for the Japanese stock market, it is able to explain the market returns in January.

The remaining of this paper proceeds as follows. Section 2 reviews literature. Section 3 presents the data and methodology. Section 4 reports the empirical results. Section 5 concludes.

\section{Literature Review}

The efficient market hypothesis posits that stock prices follow a random walk and therefore unpredictable (Fama, 1970). However, there is considerable evidence suggesting that some factors can be used to predict future stock 
returns (Bernard \& Thomas, 1989; Jegadeesh \& Titman, 1993; Stickel, 1991). One of famous market anomalies is seasonality. Rozeff and Kinney (1976) reveal that for the firms listed in the New York Stock Exchange the average returns are higher in January compared to those of the remaining months (i.e. January effect). Gultekin and Gultekin (1983) investigate the existence of seasonality for major industrialized countries and find that the January effect also exists outside the U.S.

There are several explanations for the cause of January effect. Keim (1983) suggest that the January effect is related to firm size. Gultekin and Gultekin (1983) provide evidence that the tax-loss selling hypothesis can explain the January effect. Rogalski and Tinic (1986) show that the higher returns in January may be related to the higher risk undertaken by investors in January. Ogden (1990) show that the January effect can be partially attributed to the short-term increase in investors' liquidity at the end of year.

Recently, Sun and Tong (2010) predict that investors will demand higher compensation for risk in January. They use a time-series GARCH approach to control the influence of size effect. They find that the volatility is not higher in January. Although volatility risk is positively associated with stock returns, it does not influence the magnitude of January effect. When the variable that captures the risk premium in January is added, the January effect disappears. They conclude that the January effect is caused by the higher risk compensation demanded in January.

Gultekin and Gultekin (1983) and Kato and Schallheim (1985) provide evidence that the January effect exists in the Japanese stock market. We apply the methodology used by Sun and Tong (2010) to the Japanese market and test whether their risk compensation explanations can be extended to the Japanese stock market.

\section{Sample and Methodology}

Our sample consists of Japanese public firms over the period from 1975 to 2008 . We use the basic GARCH $(1,1)$ model to test whether the volatility risk is higher in January. The model is as follows:

$$
\begin{gathered}
R_{t}=\alpha_{0}+\alpha_{1} R_{t-1}+\alpha_{2} J A N_{t}+\varepsilon_{t}, \quad \varepsilon_{t} \mid \Phi_{t-1} \sim N\left(0, h_{t}\right) \\
h_{t}=\beta_{0}+\beta_{1} h_{t-1}+\beta_{2} \varepsilon_{t-1}^{2}+\beta_{3} J A N_{t}
\end{gathered}
$$

The variables of interest are $\alpha_{2}$ and $\beta_{3}$. If there is January effect, $\alpha_{2}$ will be positive and significant. If the volatility risk in January is higher, $\beta_{3}$ will be positive and significant. $R_{t}$ represents monthly returns. The variable $\mathrm{JAN}_{\mathrm{t}}$ is an indicator. It is one when the month is January, and zero otherwise. The variable $\mathrm{h}_{\mathrm{t}}$ is the variance of $\varepsilon_{\mathrm{t}}$ conditional upon the information set $\Phi$ at the month $\mathrm{t}-1$ and follows an ARMA $(1,1)$ process.

To test whether volatility risk can explain the January effect, we use the following GARCH-M model:

$$
\begin{gathered}
R_{t}=\alpha_{0}+\alpha_{1} R_{t-1}+\alpha_{2} J A N_{t}+\alpha_{3} h_{t}+\varepsilon_{t} \\
h_{t}=\beta_{0}+\beta_{1} h_{t-1}+\beta_{2} \varepsilon_{t-1}^{2}+\beta_{3} J A N_{t}
\end{gathered}
$$

The variables of interest are $\alpha_{2}$ and $\alpha_{3}$. If volatility risk can explain the January effect, $\alpha_{3}$ is predicted to be positive and significant and $\alpha_{2}$ will decline or become insignificant.

To test whether risk compensation can explain the January effect, we use the following GARCH model:

$$
\begin{gathered}
R_{t}=\alpha_{0}+\alpha_{1} R_{t-1}+\alpha_{2} J A N_{t}+\alpha_{3} h_{t}+\alpha_{4} h_{t} * J A N_{t}+\varepsilon_{t} \\
h_{t}=\beta_{0}+\beta_{1} h_{t-1}+\beta_{2} \varepsilon_{t-1}^{2}+\beta_{3} J A N_{t}
\end{gathered}
$$

The variables of interest are $\alpha_{2}$ and $\alpha_{4}$. If risk compensation can explain the January effect, $\alpha_{4}$ is predicted to be positive and significant and $\alpha_{2}$ will decline or become insignificant.

\section{Empirical Results}

We run model (1) to check the existence of January effect and whether volatility risk is higher in January. We also divide our sample period into two sub-periods: one is from 1975 to 1984 and the other is from 1985 to 2008. We report the results in table 1 .

We use the firm level data to test our hypothesis. Panel A of table 1 reports the results of model 1 . In column 1 , the coefficient $\alpha_{2}$ is positive and significant at the 1 percent level. The result indicates that in January the mean returns are $0.39 \%$ higher than the mean of remaining months. The evidence indicates that the January effect exists in the Japanese stock market, which is consistent with Gultekin and Gultekin (1983) and Kato and Schallheim (1985). The coefficient $\beta_{3}$ is positive and significant at the 1 percent level. The result suggests that the volatility risk is higher in January. In column 2, we use model 2 to test whether the higher volatility risk in January can explain the January effect. The coefficient $\alpha_{3}$ is positive and only significant at the 10 percent level. The coefficient which captures the degree of January effect is similar. The evidence indicates that volatility risk 
is not priced in the full sample period. Volatility risk cannot explain the January effect in Japanese market. In column 3, we use model 3 to test whether risk compensation can explain the January effect in Japanese stock market. The coefficient $\alpha_{4}$ is negative and not significant. The results imply that risk compensation cannot explain the January effect in Japanese stock market.

Table 1. January effect in Japanese stock market

\begin{tabular}{|c|c|c|c|c|c|c|c|c|c|}
\hline \multirow{3}{*}{$\begin{array}{l}\text { Period } \\
\text { Model }\end{array}$} & \multicolumn{3}{|c|}{ Panel A } & \multicolumn{3}{|c|}{ Panel B } & \multicolumn{3}{|c|}{ Panel C } \\
\hline & \multicolumn{3}{|c|}{$1975-2008$} & \multicolumn{3}{|c|}{$1975-1984$} & \multicolumn{3}{|c|}{$1985-2008$} \\
\hline & 1 & 2 & 3 & 1 & 2 & 3 & 1 & 2 & 3 \\
\hline \multirow[t]{2}{*}{$\alpha_{1}$} & $0.0796^{* * *}$ & $0.0796^{* * *}$ & $0.0798^{* * *}$ & $-0.3152^{* * *}$ & $-0.3182^{* * *}$ & -0.3180 & $0.0781^{* * *}$ & $0.0782^{* * *}$ & $0.0772^{* * *}$ \\
\hline & (2010.79) & (1978.86) & (1967.89) & $(-486.6)$ & $(-491.63)$ & $(-490.84)$ & (1611.76) & $(1600.55)$ & (1597.88) \\
\hline \multirow[t]{2}{*}{$\alpha_{2}$} & $0.0039^{* * *}$ & $0.0039^{* * *}$ & $0.0041^{* * *}$ & $0.0131^{* * *}$ & $0.0130^{* * *}$ & $0.0116^{* * *}$ & $0.0015^{* * *}$ & $0.0015^{* * *}$ & $0.0017^{* * *}$ \\
\hline & (12.72) & (12.70) & (11.38) & (24.77) & (24.39) & (13.5) & $(4.11)$ & $(4.03)$ & $(4.07)$ \\
\hline \multirow[t]{2}{*}{$\alpha_{3}$} & & $0.0083^{*}$ & $0.0083^{*}$ & & $0.2753^{* * *}$ & $0.2693^{* * k}$ & & $0.0106^{* * *}$ & $0.0111^{* * *}$ \\
\hline & & $(1.80)$ & $(1.72)$ & & (13.44) & $(12.62)$ & & $(3.02)$ & (3.41) \\
\hline \multirow[t]{2}{*}{$\alpha_{4}$} & & & -0.0129 & & & $0.1963^{* *}$ & & & 0.0165 \\
\hline & & & $(-1.16)$ & & & (2.14) & & & $(1.45)$ \\
\hline \multirow[t]{2}{*}{$\beta_{1}$} & $0.1997^{* * *}$ & $0.1997^{* * *}$ & $0.1997^{* * *}$ & $0.4639^{* * *}$ & $0.4598^{* * *}$ & $0.4587^{* * k}$ & $0.2056^{* * *}$ & $0.2058^{* * *}$ & $0.2056^{* * *}$ \\
\hline & (861.9) & $(830.45)$ & $(800.45)$ & $(169.28)$ & $(166.31)$ & (166.19) & (731.32) & $(717.83)$ & (706.39) \\
\hline \multirow[t]{2}{*}{$\beta_{2}$} & $0.7912^{* * *}$ & 0.7912 & 0.7914 & $0.5450^{* * *}$ & $0.5480^{* * *}$ & $0.5495^{* * k}$ & $0.7826^{* * *}$ & $0.7823^{* * *}$ & $0.7835^{* * *}$ \\
\hline & $(3043.65)$ & (3041.47) & (3037.99) & $(291.96)$ & (294.04) & $(295.49)$ & $(2473.88)$ & (2466.24) & $(2457.41)$ \\
\hline \multirow[t]{2}{*}{$\beta_{3}$} & $0.0012^{* * *}$ & $0.0012^{* * *}$ & $0.0012^{* * *}$ & $0.0006^{* * *}$ & $0.0006^{* * *}$ & $0.0006^{* * k}$ & $0.0015^{* * *}$ & $0.0015^{* * *}$ & $0.0015^{* * *}$ \\
\hline & $(68.70)$ & $(68.88)$ & $(68.88)$ & (17.68) & (18.86) & (18.81) & $(65.88)$ & $(66.28)$ & $(66.21)$ \\
\hline $\mathrm{N}$ & 688,046 & 688,046 & 688,046 & 170,070 & 170,070 & 170,070 & 517,976 & 517,976 & 517,976 \\
\hline DW & 2.00 & 2.00 & 2.00 & 2.00 & 2.00 & 2.00 & 2.00 & 2.00 & 2.00 \\
\hline
\end{tabular}

Note. Significance at the $10 \%, 5 \%$, and $1 \%$ levels is denoted by $*, * *, * * *$.

We divide the sample period into two sub-periods for the following two reasons. On the one hand, behavior finance literature implies that anomalies usually disappear after they are released to the public. On the other hand, the Japanese economy experiences a long-term recession in the entire 1990s as a result of the Plaza Agreement in September of 1985. The economic condition may have a significant impact on the Japanese stock market.

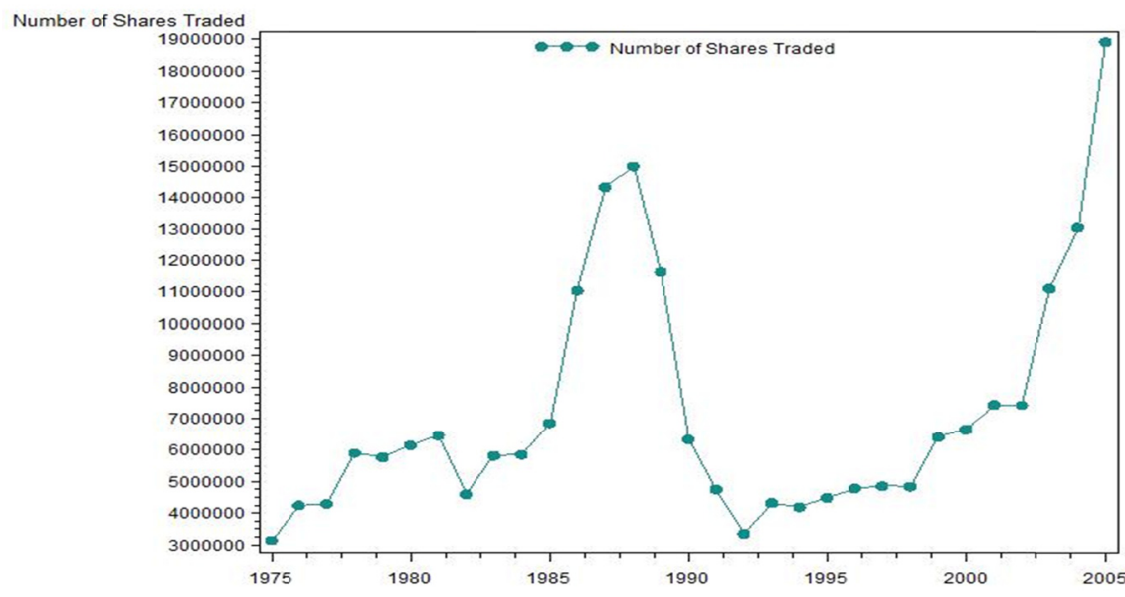

Figure 1. Market trading volume over the period 1975 to 2005

In Panel B of Table 1, we report the results of models 1-3 for the earlier period. We find that the volatility risk is lower and the degree of January effect is greater for this sub-period. The coefficient $\alpha_{3}$ is positive and significant. The coefficient $\alpha_{2}$ is similar after the volatility risk is added in GARCH model. The evidence 
implies that the volatility risk is priced but it is not the primary cause for the January effect. In Panel C of table 1 , we report the results of models 1-3 for the second sub-period. Evidence indicates that the volatility risk is higher in January but the January effect is much weaker compared to the earlier period. The volatility risk is also less priced in the second period.

We posit that the lower degree of January effect in the sub-period 1985 to 2008 may be related to Japanese long-term economic recession in the entire 1990s. We compute the average monthly trading volume of Japanese stock market for each year and present the result in Figure 1.

Figure 1 shows that the behavior of average monthly trading volume differs significantly before and after the year 1985. In the first sub-period, the trading volume climbs steadily and does not fluctuate much. The average trading volume is about 5 million shares per month. In the second sub-period, the trading volume rises to its peak of about fifteen million shares per month in 1988 and then declines quickly in the following four years. In 1992 the monthly trading volume drops to the bottom. For the entire 1990s the average monthly trading volume is below that of the first sub-period.

We argue that the behavior of monthly trading volume reflects the impact of economic slowdown on Japanese stock market. When the economic environment is bad, the uncertainty of corporate investment is high. It can explain why the market risk is higher in January in the second sub-period. Literature indicates that companies will reduce corporate investment when uncertainty is high (Chen, Goldstein, \& Jiang, 2007; Foucault \& Fresard, 2014). It implies that the demand for external financing is lower. As a result, the expected market returns will decline. It can explain why the degree of January effect in the second sub-period is lower.

Next we sort firms by size and form three stock portfolios. We run models 1-3 to each portfolio to examine how firm size influences our findings.

Table 2. January effect in Japanese stock market: evidence from firm size

\begin{tabular}{|c|c|c|c|c|c|c|c|c|c|}
\hline \multirow{2}{*}{ Model } & \multicolumn{3}{|c|}{ Small } & \multicolumn{3}{|c|}{ Middle } & \multicolumn{3}{|c|}{ Large } \\
\hline & 1 & 2 & 3 & 1 & 2 & 3 & 1 & 2 & 3 \\
\hline \multicolumn{10}{|c|}{ Panel A: 1975-1984 } \\
\hline \multirow[t]{2}{*}{$\alpha_{1}$} & $-0.3467^{* * *}$ & $-0.3485^{* * *}$ & $-0.3489^{* * *}$ & $-0.3313^{* * *}$ & $-0.3350^{* * *}$ & $-0.3354^{* * *}$ & & $-0.3023^{* * *}$ & $-0.3021^{* * *}$ \\
\hline & $(-327.68)$ & $(-327.23)$ & $(-326.76)$ & $(-200.07)$ & $(-200.03)$ & $(-200.23)$ & $(-176.5)$ & $(-177.78)$ & $(-177.54)$ \\
\hline \multirow[t]{2}{*}{$\alpha_{2}$} & $0.0118^{* * *}$ & $0.0109^{* * *}$ & $0.0155^{* * *}$ & $0.0087^{* * *}$ & $0.0077^{* * *}$ & $0.0103^{* * *}$ & $0.0113^{* * *}$ & $0.0097^{* * *}$ & $0.0081^{* * *}$ \\
\hline & $(7.43)$ & $(6.77)$ & $(4.59)$ & $(7.59)$ & $(6.65)$ & $(4.16)$ & (11.63) & $(9.96)$ & $(5.25)$ \\
\hline \multirow[t]{2}{*}{$\alpha_{3}$} & & $0.1471^{* * *}$ & $0.1657^{* * *}$ & & $0.3942^{* * *}$ & $0.4186^{* * *}$ & & $0.4709^{* * *}$ & $0.4475^{* * *}$ \\
\hline & & $(3.83)$ & $(4.51)$ & & $(8.65)$ & $(9.21)$ & & $(7.72)$ & $(7.02)$ \\
\hline \multirow[t]{2}{*}{$\alpha_{4}$} & & & -0.3301 & & & -0.2703 & & & 0.3138 \\
\hline & & & $(-1.57)$ & & & $(-1.07)$ & & & $(1.23)$ \\
\hline \multirow[t]{2}{*}{$\beta_{1}$} & $0.6698^{* * *}$ & $0.6612^{* * *}$ & $0.6617^{* * *}$ & $0.5466^{* * *}$ & $0.5387^{* * *}$ & $0.5393^{* * *}$ & $0.3570^{* * *}$ & $0.3547^{* * *}$ & $0.3549^{* * *}$ \\
\hline & $(94.43)$ & $(94.03)$ & $(93.16)$ & $(67.86)$ & $(66.86)$ & $(66.73)$ & $(80.11)$ & $(78.58)$ & $(78.50)$ \\
\hline \multirow[t]{2}{*}{$\beta_{2}$} & $0.2794^{* * *}$ & $0.2864^{* * *}$ & $0.2849^{* * *}$ & $0.4009^{* * *}$ & $0.4078^{* * *}$ & $0.4064^{* * *}$ & $0.7298^{* * *}$ & $0.7307^{* * *}$ & $0.7309^{* * *}$ \\
\hline & $(52.05)$ & $(53.44)$ & $(52.92)$ & $(76.82)$ & $(75.88)$ & $(75.42)$ & (343.39) & $(343.77)$ & (343.17) \\
\hline \multirow[t]{2}{*}{$\beta_{3}$} & $0.0049^{* * *}$ & $0.0050^{* * *}$ & $0.0050^{* * *}$ & $0.0022^{* * *}$ & $0.0023^{* * *}$ & $0.0023^{* * *}$ & $0.0015^{* * *}$ & $0.0015^{* * *}$ & $0.0015^{* * *}$ \\
\hline & $(39.02)$ & $(38.63)$ & $(38.67)$ & $(19.41)$ & (20.18) & $(20.12)$ & $(43.52)$ & $(43.62)$ & $(43.47)$ \\
\hline DW & 2.01 & 2.01 & 2.01 & 2.01 & 2.01 & 2.01 & 2.01 & 2.01 & 2.01 \\
\hline \multicolumn{10}{|c|}{ Panel B: 1985-2008 } \\
\hline \multirow[t]{2}{*}{$\alpha_{1}$} & $-0.2091^{* * *}$ & $-0.2107^{* * *}$ & $-0.2107^{* * *}$ & $-0.1267^{* * *}$ & $-0.1272^{* * *}$ & $-0.1265^{* * *}$ & $-0.1353^{* * *}$ & $-0.1357^{* * *}$ & $-0.1355^{* * *}$ \\
\hline & $(-263.05)$ & $(-236.16)$ & $(-262.40)$ & $(-214.82)$ & $(-214.24)$ & $(-211.70)$ & $(-257.37)$ & $(-271.06)$ & $(-258.32)$ \\
\hline \multirow[t]{2}{*}{$\alpha_{2}$} & $-0.0040^{* * *}$ & $-0.0044^{* * *}$ & 0.0005 & $0.0034^{* * *}$ & $0.0028^{* *}$ & $0.0105^{* * *}$ & $0.0049^{* * *}$ & $0.0048^{* * *}$ & $0.0073^{* * *}$ \\
\hline & $(-4.19)$ & $(-4.59)$ & $(0.33)$ & $(2.92)$ & $(2.42)$ & $(4.27)$ & $(4.88)$ & (4.69) & (4.19) \\
\hline \multirow[t]{2}{*}{$\alpha_{3}$} & & $0.2539^{* * *}$ & $0.2797^{* * *}$ & & $0.1888^{* * *}$ & $0.2019^{* * *}$ & & $0.1009^{* * *}$ & $0.1052^{* * *}$ \\
\hline & & $(8.02)$ & $(8.18)$ & & (11.89) & (14.33) & & $(7.42)$ & (7.99) \\
\hline \multirow[t]{2}{*}{$\alpha_{4}$} & & & $-0.3504^{* * *}$ & & & $-0.5050^{* * *}$ & & & $-0.2227^{*}$ \\
\hline & & & $(-3.96)$ & & & $(-3.53)$ & & & $(-1.77)$ \\
\hline \multirow[t]{2}{*}{$\beta_{1}$} & $0.3751^{* * *}$ & $0.3752^{* * *}$ & $0.3745^{* * *}$ & $0.2253^{* * *}$ & $0.2244^{* * *}$ & $0.2233^{* * *}$ & $0.2425^{* * *}$ & $0.2420^{* * *}$ & $0.2419^{* * *}$ \\
\hline & (121.31) & $(116.12)$ & (116.14) & (132.21) & (130.69) & (130.74) & $(205.45)$ & (195.36) & (188.27) \\
\hline \multirow[t]{2}{*}{$\beta_{2}$} & $0.5583^{* * *}$ & $0.5568^{* * *}$ & $0.5575^{* * *}$ & $0.7060^{* * *}$ & $0.7066^{* * *}$ & $0.7080^{* * *}$ & $0.7227^{* * *}$ & $0.7230^{* * *}$ & $0.7231^{* * *}$ \\
\hline & $(202.06)$ & (201.89) & (202.59) & $(364.03)$ & $(365.57)$ & $(367.55)$ & (439.12) & $(396.60)$ & $(398.28)$ \\
\hline
\end{tabular}




\begin{tabular}{lcccccrrrr}
\hline$\beta_{3}$ & $0.0019^{* * *}$ & $0.0022^{* * *}$ & $0.0022^{* * *}$ & $0.0040^{* * *}$ & $0.0042^{* * *}$ & $0.0042^{* * *}$ & $0.0021^{* * *}$ & $0.0021^{* * *}$ & $0.0022^{* * *}$ \\
& $(19.55)$ & $(21.22)$ & $(21.31)$ & $(88.15)$ & $(91.57)$ & $(91.03)$ & $(38.65)$ & $(39.32)$ & $(39.25)$ \\
$\mathrm{DW}$ & 2.01 & 2.01 & 2.01 & 2.01 & 2.01 & 2.01 & 2.01 & 2.01 & 2.01 \\
\hline
\end{tabular}

Note. Significance at the $10 \%, 5 \%$, and $1 \%$ levels is denoted by $*, * *, * * *$.

Panel A of table 2 reports the results over the sub-period from 1975 to 1984 . For each portfolio the coefficient $\alpha_{2}$ obtained by model 1 is positive and significant. The result indicates that the January effect exists for both small and large firms. The magnitude of $\beta_{3}$ decreases as firm size grows. The result implies that for small firms volatility risk in January is higher than large firms. But the degree of January effect does not increases as firm size grows. In fact, the evidence indicates that the relation between firm size and the degree of January effect is U-shaped. The result is consistent with the view that the January effect is not mainly caused by firm size. In model 2 the coefficient $\alpha_{3}$ captures volatility risk. When it is added, the degree of January effect only decreases a little. The evidence suggests that volatility risk can only explain a small proportion of January effect. We find that the magnitude of $\alpha_{3}$ increases as firm size grows. It implies that for small firms volatility risk is less priced than large firms. In January, the volatility risk is lower but it is higher priced for large firms. The results suggest that investors can take use of this anomaly to make more profits by bearing lower risk. After January effect is released to the public, we predict that the profit-making opportunity will disappear in the second sub-period. In model 3, the coefficient $\alpha_{4}$ is negative for small firms and positive for large firms. When the variable that captures risk compensation is added, the degree of January effect does not decline. The result is consistent with our findings that risk compensation does not explain the January effect in Japanese stock market. We notice that the risk compensation is higher for large firms but lower for small firms in January. The result provides additional evidence that in the first sub-period investing in large firms is more profitable than investing in small firms.

Panel B of table 2 reports the results over the sub-period from 1985 to 2008. In the sub-period, we find that the coefficient $\alpha_{2}$ obtained by model 1 is negative and significant at the 1 percent level for small firms. For large firms, the January effect is positive and significant. In addition, the degree of January effect increases as firm size grows. The evidence implies that in the second sub-period the January effect can be partially attributed to firm size. In model 2, we find that the coefficient $\beta_{3}$ is positive and significant. The result suggests that volatility risk is higher in January. The coefficient $\alpha_{3}$ is positive and significant, implying that volatility risk is priced. The degree of January effect does not change much when volatility risk is added. The evidence implies that volatility risk cannot explain January effect. In model 3, we find that for small firms the coefficient $\alpha_{2}$ becomes insignificant when risk compensation is added. The coefficient $\alpha_{4}$ is negative and significant at the 1 percent level. The results indicate that risk compensation can explain the lower average returns in January for small firms. For larger firms, we obtain similar results. The degree of January effect becomes more pronounced when the risk compensation term is added. The results indicate that although risk compensation is not the primary cause for January effect, it will influence the average market returns in January for the Japanese stock market.

We compare the coefficient $\alpha_{3}$ between the two sub-periods and observe interesting phenomenon. For the first sub-period, volatility risk pricing increases as firm size grows. The result implies that higher returns are demanded to compensate for bearing volatility risk for large firms. In comparison, for the second sub-period, volatility risk pricing decreases as firm size grows. We interpret the findings as follows. Since the volatility risk is lower for large firms but the volatility risk is higher priced in the first sub-period, investors are more willing to buy the stocks of large firms to earn positive risk-adjusted abnormal returns in the second sub-period. As more and more investors engage in the profit-making transaction, the demanded returns to compensate for bearing volatility will decrease for large firms. At the same time, as fewer investors invest in small firms, the demanded returns to compensate for bearing volatility risk will go up. The evidence on the relations between the coefficient $\alpha_{3}$ and firm size implies that investors take use of anomalies to make abnormal profits.

\section{Conclusion}

In this research we apply Sun and Tong (2010)'s methodology to the Japanese stock market. We find that the January effect is more pronounced for the sub-period 1975 to 1984 . We provide evidence that the Japanese economic recession since the early 1990s may partially contribute to the phenomenon. We provide evidence that volatility risk is higher in January, although it is not the primary cause for the January effect. We show that risk compensation in January can explain the market returns in January. We also provide evidence that investors take use of seasonality to make abnormal profits. 


\section{References}

Bernard, V. L., \& Thomas, J. K. (1989). Post-earnings-announcement drift: Delayed price response or risk premium? Journal of Accounting Research, 27(Supplement), 1-36. http://dx.doi.org/10.2307/2491062

Campbell, J. Y., \& Hamao, Y. (1992). Predictable stock returns in the United States and Japan: A study of long-term capital market integration. Journal of Finance, 47(1), 43-69. http://dx.doi.org/10.2307/2329090

Chen, Q., Goldstein, I., \& Jiang, W. (2007). Price Informativeness and Investment Sensitivity to Stock Price. Review of Financial Studies, 20(3), 619-650. http://dx.doi: 10.1093/rfs/hhl024

Fama, E. F. (1970). Efficient capital markets: A review of theory and empirical work. Journal of Finance, 25(2), 383-417. http://dx.doi.org/10.2307/2325486

Foucault, T., \& Fresard, L. (2014). Learning from peers' stock prices and corporate investment. Journal of Financial Economics, 111(3), 554-577. http://dx.doi: 10.1016/j.jfineco.2013.11.006

Gultekin, M. N., \& Gultekin, N. B. (1983). Stock market seasonality: International evidence. Journal of Financial Economics, 12(4), 469-481. http://dx.doi.org/10.1016/0304-405X(83)90044-2

Jegadeesh, N., \& Titman, S. (1993). Returns to buying winners and selling losers: Implications for stock market efficiency. Journal of Finance, 48(1), 65-91. http://dx.doi.org/10.2307/2328882

Kato, K., \& Schallheim, J. S. (1985). Seasonal and size anomalies in the Japanese stock market. Journal of Financial and Quantitative Analysis, 20(2), 243-260. http://dx.doi.org/10.2307/2330958

Keim, D. B. (1983). Size-related anomalies and stock return seasonality: Further empirical evidence. Journal of Financial Economics, 12(1), 13-32. http://dx.doi.org/10.1016/0304-405X(83)90025-9

Ogden, J. P. (1990). Turn-of-month evaluation of liquid profits and stock returns: A common explanation for the monthly and January effects. Journal of Finance, 45(4), 1259-1272. http://dx.doi.org/10.2307/2328723

Rogalski, R. J., \& Tinic, S. M. (1986). The January size effect: Anomaly or risk mismeasurement? Financial Analysts Journal, 42(6), 63-70. http://dx.doi.org/10.2469/faj.v42.n6.63

Rozeff, M. S., \& Kinney, W. R. (1976). Capital market seasonality: The case of stock returns. Journal of Financial Economics, 3(4), 379-402. http://dx.doi.org/10.1016/0304-405X(76)90028-3

Stickel, S. E. (1991). Common stock returns surrounding earnings forecast revisions: More puzzling evidence. The Accounting Review, 66(2), 402-416.

Sun, Q., \& Tong, W. H. S. (2010). Risk and the January effect. Journal of Banking \& Finance, 34(5), 965-974. http://dx.doi: 10.1016/j.jbankfin.2009.10.005

\section{Note}

Note 1. Our sample period ends at the year 2008 to avoid the influence of the 2008 financial crisis. The sample period of Sun and Tong (2010) is from 1926 to 2005, which excludes the 2008 financial crisis. To make our results comparable to Sun and Tong (2010), we do not include the 2008 financial crisis in our study.

\section{Copyrights}

Copyright for this article is retained by the author(s), with first publication rights granted to the journal.

This is an open-access article distributed under the terms and conditions of the Creative Commons Attribution license (http://creativecommons.org/licenses/by/3.0/). 